\title{
Herding Behavior in Nepali Stock Market: Empirical Evidences based on Investors from NEPSE
}

\author{
Nischal Risal, M.Phil. \\ Lecturer \\ Nepal Commerce Campus, Faculty of Management, T.U. \\ Nitesh Khatiwada \\ Banking Personnel
}

\begin{abstract}
The research paper aims to examine the attitudinal factors influencing herding behavior in order to manage the fluctuations, bubbles, and bursts in the Nepali capital market. The descriptive and analytical research design have been adopted in the study. The qualitative data has been collected through the structured, self-administered questionnaire distributed to five hundred investors of the securities market in Nepal. The usable questionnaires have been confined to 407 responses. The statistical tools mean, percentages, correlation and regression analysis have been done to process the data towards findings. As the result, the decision accuracy, age and experiences have not been found significant. The result from the analysis revealed the significant relationship of hasty decision with herd behavior.
\end{abstract}

Keywords: Financial Market; Behavioral Finance; Attitudinal Factors; Hasty Decision; Decision Accuracy

\section{Introduction}

The study of attitudinal factors determining the individual investors' herd behavior is very important in the recent years. The claim of classical finance that the investors are rational becomes questionable. The investors also make decision on the basis of their emotions which results bubbles in the stock market. The classical financial theorist hypothesized that the market is efficient, investors are rational, and investors' choices are based on the rational decisions. However, the classical theory could not explain the fluctuations in the financial markets and market crashes over the time. So, the behavioral finance study came into existence because the conventional economic theory with its math, models and equations could not explain anomalies happening in the financial management.

The herding behavior in the stock market can take three forms. Information-based herding happens when everyone reacts the same way to announced information. Reputation-based herding is caused by a respected investor or major trading house taking a specific trading stance. Compensation-based herding occurs when certain conditions prompt large institutional money managers to take profits, generally to protect fund earnings before year-end reporting. These behaviors create large volume in certain stocks or sectors that are popular institutional portfolio investments, prompting those watching to react quickly.

There are many instances in Nepali as well as the world primary financial market where under rated shares of companies are oversubscribed. In the secondary market as well, the price of the shares fluctuates like the movement of a pendulum, often oscillating between the lows and highs. The oversubscription of underrated shares is not a rational decision. The trend clearly shows that people are driven by other 
psychological factors and most of them follow what other is doing without making their rational judgments. The behavioral finance tries to identify the gap between economic doctrine and real-life inconsistencies by taking human emotion into account.

Among various dimensions of behavioral finance, the most prominent and pervasive one is herd behavior. The existing literatures have shown that the people value safety in numbers and by the same means, investors take comfort from what others are doing. The reasons for herding may be primal emotions surrounding fear and rewards that corrupt rational decision-making which may lead to hasty decision and competition that ultimately create overconfidence in the investors. Hence, the need for rapid decision making as important news flashes on trading screens can put traders and investors in vulnerable situations, so, investors sometimes make themselves feel more secure by following the herd. While herding is not common when considered against the massive volume of trading that occurs on a daily basis, during event uncertainties in the financial markets it is more common for traders and investors to act as others have acted.

\section{Conceptual Framework and Literature Review}

The current study describes the herd behavior as investment behavior, and has tried to explain the behavior through some demographic and attitudinal factors. In the context, the study differs from some other studies which deal with herd behavior as a determinant of investment behavior. The study tries to examine these relationships among individual investors in the NEPSE which represent the only secondary market in Nepal. The main hypothesis of the study is herding behavior of individual investors is affected by some attitudinal factors which include decision accuracy, and hasty decision. The relationship is also checked under the moderation of the demographic factors namely age and investment experience. The figure has represented the theoretical framework of the study.

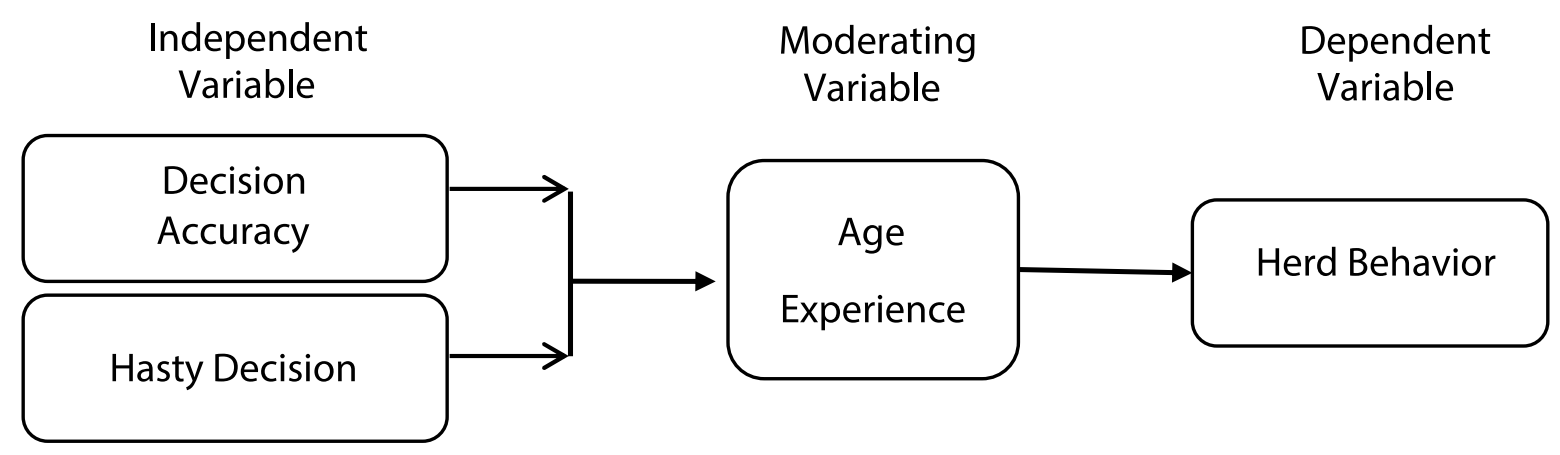

Figure 1: Conceptual Framework

Literature review in the field of herd behavior is concentrated in three main trends. The first trend focuses on whether herd behavior exists in financial markets. Most of these studies confirm that herd behavior is most common in emerging markets. Adhikari (2010) and Dangol \& Sthapit (2017), had revealed the same was true in Nepal as well. Another research stream of herd behavior has focused on the differences between individuals and institutional investors on adopting herd behavior. And, few empirical studies explain exactly what causes herding. Research that shows the relationship between different attitudinal factors and herd behavior is scarce. Only one research is conducted till date to access the impact of decision accuracy, hasty decision and investor's mood in adopting the herd behavior. The results of Shusha \& Touny (2016), clearly indicate positive impact of these factors in adopting herd behavior. When it comes to similar research in Nepal, any related literature could not be found. One major determinant of herding behavior was trading volume of market in Malaysia (Ah Mand, et.,al, 2018). Hence, the study tried to assess whether 
Vol. 4, No. 1

hasty decision and decision accuracy are the determinants of adopting herd behavior in Nepal.

In presence of moderating variables namely experience and age, Shusha \& Touny (2016) found that experience of investor has a significant negative impact on the tendency of investors to adopt herd behavior. However, the gender of investor did not show any moderating role between attitudes of investors and their tendency to adopt herd behavior. Thus, the study tries to assess the relationship between the decision accuracy, hasty decision and overconfidence and herd behavior along with moderating variable i.e. investment experience and age.From the past literature it can be seen that several studies have been done to analyze the herd behavior in stock markets. Specifically, the study on the attitudinal determinants of herd behavior among NEPSE investors is nonexistent. Hasty decision and distortion in accurate decision are created when individual investors decide to take investment decision of others into account while making their investment decision.

The trend persists even if each individual know that everyone was behaving in herd like behavior (Thaler, 1993).Investors simply thought that all the other people could not be wrong. They were reacting to the information that a large group of people had reached a decision different from theirs. Thus, they herd while making decision and for them the decision was a rational behavior (Shiller, 2000).

There are two polar views in which the investment behavior of the financial market participants is categorized, the traditional finance approach, and behavioral finance approach. The researcher had taken into account the difference existing in market conditions and found the evidence of herding behavior during rising markets only for Golf Cooperation Council (GCC) markets. The result was confirmed after using the quantile regression method, as evidence of herding was observed only in highly extreme periods. The stock returns had performed more similarly when market was down in Islamic GCC stock market (Chaffai, 2017).

\section{Traditional finance}

Shleifer, (2000) had explained that the efficient market hypothesis (EMH) has a certain proposition. The frictions did not exist and hence, a security price was equal to fundamental value. The discounted sum of expected future cash flow had represented the fundamental value, thus the investors could process the available information accurately and the discount rate was consistent with the accepted preference specification. Henceforth, the financial price had incorporated the available information, agents were rational, and prices were the optimal assessment of true investment value. In an efficient market, regardless of applied investment strategy, average returns were equal to the risk taken (Barberis \& Thaler, 2003). As a result, financial assets were always priced rationally, security prices approximately described random walks through time and it was impossible to make above average profit and beat the market over time without taking an excess risk (Shiller, 2000).

\section{Behavioral finance}

Nicholson (1968) and Basu (1977) challenged the efficiency of security price by suggesting that stocks with high price to earnings ratio was overvalued and stock with a low price to earnings ratio was undervalued. The disparity in classical financial theory was more eminent in the 1980s when several empirical findings were inconsistent with EMH (Shefrin, 2000). Keim (1983) documented calendar effects where the daily return distributions in January were abnormal relative to the remaining eleven months. Bondt \& Thaler (1995) proved that stock market to over reacting to market information.

Furthermore, Shefrin \& Statman (1985) postulated that stockholders were more willing to sell their winning stocks rather than losing one's even when putting these losers on sale was the best choice. Researchers provided additional evidence on more market anomalies which were inconsistent with EMH approach to the financial market.

In the light of anomalies found and the difficulty of traditional finance models based on the EMH to explain these anomalies a new field of finance, namely behavioral finance, emerged. The approach offered a 
possible explanation for the previous stock crashes and empirical puzzles not easily understood by the EMH (Devenow \& Welch, 1996).

Being different from the EMH theory, behavioral finance believes that sometimes, financial markets do not have an informational efficiency (Ritter, 2003).

Due to the fact that people are not always rational, their financial decisions are at times driven by behavioral preconceptions. In case the decisions of people do not follow rational thinking, effects of behavioral biases should be identified. It will be more important if their cognitive errors affect prices and are not arbitraged away easily (Kim \& Nofsinger, 2008). Recently, "the ramifications of less-than rational agents" have been explored based on many theoretical models. At first, most of the studies concentrated on asset pricing, however, recently, many models incorporate the effects rather than rational ones that managers may have in decision-making process.

\section{Decision and Herding}

Even completely rational people can participate in herd behavior when they take into account the decision of others, and even if they know that everyone is behaving in herd like manner. The behavior, although individually rational, produces group behavior that is irrational and causes fluctuations in the market. The "noise trading" theory stems from the fact that investors with a short time horizon are influencing the stock price more than the long- term investors are. Investors, with no access to inside information, irrationally act on noise as if it were information that would give them an edge (Thaler, 1993).

Scharfstein \& Stein (1990) and Bikhchandani \& Sharma (2001) had explained that the herding behavior can be rational or irrational. Herding can be rational if the investor's actions are intentional whereas irrational herding means that the actions of the investor are non-intentional as the investor disregards his prior beliefs and blindly follows other investors' decisions (Christie \& Huang, 1995; Devenow \& Welch, 1996). Rational herding can be supported by the theory of planned behavior which assumed that planned behavior can be used in anticipating human behavior, where the theory of reasoned action supposed that intentions can be considered as a mediator variable between the behavioral motivators and the behavior itself (Ajzen \& Fishbein, 1980; Ajzen, 1991, 2002).

The social influence has an immense power on individual decision. When people are confronted with the decision of a large group of people, they tend to change their "wrong" answers. They simply think that all the other people could not be wrong. They are reacting to the information that a large group of people had reached a decision different from theirs. The is a rational behavior. In everyday living as well we have learned that when a large group of people is unanimous in its decisions they are certainly right (Shiller, 2000). People are influenced by their social environment and they often feel pressure to conform. Fashion is a mild form of herd behavior while an example of the strong form is furors that constitute speculative bubbles and crushes. Herd behavior may be the most generally recognized observation on financial markets in a psychological context.

The herding effect in financial market is identified as tendency of investors' behaviors to follow the others' actions. Practitioners usually consider carefully the existence of herding, due to the fact that investors rely on collective information more than private information can result the price deviation of the securities from fundamental value; therefore, many good chances for investment at the present can be impacted. Academic researchers also pay their attention to herding; because its impacts on stock price changes can influence the attributes of risk and return models and has impacts on the viewpoints of asset pricing theories (Tan, Chiang, Mason, \& Nelling, 2008).

Shusha \& Touny (2016), examined four attitudinal determinants which include decision accuracy, hasty decision, overconfidence, and investor mood, and tested to what extent the effects of these determinants differ according to demographic characteristics of individual investors such as gender, educational level, age, experience, and income. The study collected data by questionnaire and covered 255 respondents. The results of the estimated models indicated that decision accuracy, hasty decision, and investor mood were 
Vol. 4, No. 1

the main attitudinal determinants that explain why individual investors follow herd behavior. However, overconfidence seems to have no effect on adopting herd behavior in all models.

\section{Objectives}

The major objective of the study is to analyze the herding behavior in Nepali stock market. The other specific objectives are as under;

To access the influence of decision accuracy, and hasty decision on the adaptation of herd behavior.

To identify the most influencing variables in determining the herd behavior of NEPSE investors.

\section{Hypothesis}

$H_{1}:$ Hasty Decision has significant impact in adopting herd behavior.

$\mathrm{H}_{2}$ : Decision Accuracy has significant impact in adopting herd behavior.

$H_{3}:$ Hasty decision moderated by age significantly affects the adoption of herd behavior.

$H_{4}$ : Decision accuracy moderated by age significantly affect the adoption of herd behavior.

$H_{5}:$ Hasty decision moderated by investment experience significantly affects the adoption of herd behavior.

$H_{6}:$ Decision accuracy moderated by investment experience significantly affect the adoption of herd behavior.

\section{Research Methods}

A descriptive and analytical research design were adopted in the study. The data had been collected through the self-administered structured questionnaire distributed among 500 individual investors of the securities market in Nepal. The questionnaire consisted dichotomous, ranking and Likert scale questions. The population was unknown, thus the sample had been strict to at least 384. Finally, the responses from 407 observations were processed and analyzed using SPSS 20.0 software. The mean, percentages, correlation and regression analysis had been done. The Cronbach's alpha measure had been used to test the reliability. The normality, homoscedasticity tests test were also run in the study.

Table 1 Regression Model

\begin{tabular}{llll}
\hline Regression & Model & Equation & Notation \\
\hline Univariate & 1 & $H B=\beta_{0}+\beta_{2} H D+\square$ & $H B=$ Herd Behavior \\
& 2 & $H B=\beta_{0}+\beta_{3} D A+\square$ & $\beta_{0}=$ Constant Term \\
& & $H D=$ Hasty Decision \\
Multiple & 3 & $H B=\beta_{0}+\beta_{1} H D+\beta_{3} D A+\square$ & $\begin{array}{l}D A=\text { Decision Accuracy } \\
\end{array}$ \\
\hline
\end{tabular}

The attitudinal factors determining herd behavior among individual investor of Nepal was analyzed. The questions regarding impact of overconfidence, hasty decision, decision accuracy, age and experience of the investors in adopting herd behavior were central to the study. In the context, an empirical approach was followed where the active investors were sought and opinions regarding their investment activities were recorded. The selected respondents were the proxies of the investors in Nepal. The study had left the ground to examine the other dimensions such as mood, insights, peer pressure, market factor, motivation that might affected the herd behavior of individual investors. 


\section{Results}

\section{Descriptive analysis}

The response rate was found to be 81.4 percentages. The majority of the respondents were male i.e, 63 percentages. The 59 percentages of the respondents were aged above thirty years. The 68 percentages of the respondents had working experiences of more than five years. The investors having more than five years investment experiences stood at 52 percentages.

\section{Correlation analysis}

The correlation analysis between the herd behavior, and independent variables had been carried out to analyze the degree and direction of relationship among the variables. The strong correlation had depicted the high explanatory power of the independent variable. The decision accuracy variable was found low and negative, which had indicated the weak predictive variable for herd behavior. The result of pair wise correlations had indicated that the data of independent variables were free from multi-collinearity problem.

The table presents the Spearman's Rho Correlation and Pearson Correlation analysis between the variables taken under the study. Specifically, the table shows the correlation between dependent and independent variables. It compares the sign with prior expectation which also helps in regression analysis. The dependent variable of the study was herd behavior and independent variables were hasty decision and decision accuracy.

Table 2 Correlations Matrix

\begin{tabular}{|l|c|c|c|}
\hline \multicolumn{1}{|c|}{ Spearman's rho } & Herd Behavior & Hasty Decision & Decision Accuracy \\
\hline Pearson & 1 & $.345^{* *}$ & -.008 \\
\hline Herd Behavior Decision & $.464^{* *}$ & 1 & $.240^{* *}$ \\
\hline Decision Accuracy & .094 & $.275^{* *}$ & 1 \\
\hline
\end{tabular}

\section{Regression analysis}

\section{Regression analysis without moderators}

The table presents the regression analysis of attitudinal factors of the investors that impact herd behavior, where the dependent variables is investors' herd behavior and independent variables (attitudinal factors) are overconfidence (OC), hasty decision (HD) and decision accuracy (DA), The result was based on 407 observations computed using linear regression model stated as under:

$$
Y_{1}=\beta_{0}+\beta_{1} D A+\beta_{2} H D+\beta_{3} O C+
$$

The figures in the parentheses ( ) are t-values. Figures in \{\} are VIF values. * denotes that the results are significant at $1 \%$ level of significance. $* *$ denotes that the results are significant at $5 \%$ level of significance. ${ }^{* * *}$ denotes that the results are significant at $5 \%$ level of significance.

The table 3 has shown the regression analysis of the relationship between the attitudinal dimensions and herd behavior, where the model excludes the moderating variables. The model 1 and 2 has shown the univariate analysis of relationship of herd behavior as dependent variable with other independent variables: hasty decision and decision accuracy respectively. The beta coefficient of hasty decision was found 0.456 , and significant at 1 percentages level of significance. On the other hand, the beta coefficient of decision accuracy, was found 0.092 , and significant at 10 percentages level of significance. The coefficients of determination of each of the model were 26.1 
Vol. 4, No. 1

percentage, and 0.9 percentages respectively. The result also reported the F-value of 111.33 , and 3.648 in each model, however, the F-statistics in the model two was significant at 10 percentages level of significance. The regression analysis presented in model 3 constituted the relation between independent variables hasty decision and decision accuracy with herd behavior. The model has shown that the explanatory power of hasty decision had been improved; however, decision accuracy loses to explain the relationship as its coefficient was not only negative but insignificant as well. The coefficients of determination of the model was 21 percentages, F-statistics was 55.923 and significant at 1 percentage level of significance.

Table 3 Regression Analysis without Moderators

\begin{tabular}{|c|c|c|c|c|c|c|}
\hline \multirow{2}{*}{ Model } & \multirow{2}{*}{ Constant } & \multicolumn{2}{|c|}{ Beta Coefficient } & \multirow[t]{2}{*}{$\mathrm{R}^{2}$} & \multirow[t]{2}{*}{ Adj. $\mathrm{R}^{2}$} & \multirow[t]{2}{*}{$\mathrm{F}$} \\
\hline & & HD & $\mathrm{DA}$ & & & \\
\hline \multirow{3}{*}{1} & \multirow{3}{*}{1.07} & 0.459 & & \multirow{3}{*}{0.22} & \multirow{3}{*}{0.21} & \multirow{3}{*}{$111.33 *$} \\
\hline & & $(10.55)^{*}$ & & & & \\
\hline & & $\{1.0\}$ & & & & \\
\hline \multirow{3}{*}{2} & \multirow{3}{*}{1.84} & & 0.091 & \multirow{3}{*}{0.01} & \multirow{3}{*}{0.01} & \multirow{3}{*}{$3.64 * * *$} \\
\hline & & & $(1.91)^{* * *}$ & & & \\
\hline & & & $\{1.0\}$ & & & \\
\hline \multirow{3}{*}{3} & \multirow{3}{*}{1.13} & 0.469 & -0.035 & \multirow{3}{*}{0.22} & \multirow{3}{*}{0.21} & \multirow{3}{*}{$55.92 *$} \\
\hline & & $(10.36)^{*}$ & $(-0.788)$ & & & \\
\hline & & $\{1.1\}$ & $\{1.1\}$ & & & \\
\hline
\end{tabular}

\section{Regression Analysis with Moderators}

The table 4 presents the summary of the multiple regression analysis coefficients of all the regression models presented in the study. The dependent variable is investors' herd behavior, independent variables are decision accuracy, hasty decision, and overconfidence and moderating variables are age and investment experience. The regression model is:

$$
Y_{1}=\beta_{0}+\beta_{1} D A+\beta_{2} H D+\beta_{3} O C
$$

$*$ denotes that the results are significant at $1 \%$ level of significance. $* * *$ denotes that the results are significant at $5 \%$ level of significance.

With the aim to examine the effect of moderating variables, the regression analysis had been conducted introducing the third variables: age and investment experience. The results had reported separately for age and investment experience. In order to assess the effect of different age of the respondents, their age had been grouped as the respondents belonging the age under 30 years and the age 30 and above. Similarly, there had been two categories of investment experience namely those having experience below five years and those having experience equal to and above five years. The univariate and multiple regression analysis had been conducted to assess the impact of the moderators in the adaptation of the herd behavior. The result had indicated no significant impact of the variables in the relationship between the independent and dependent variables. The table 3 presented the summary of the multiple regression model of the study when moderated by age and investment experience for quick comparison. The hasty decision variables had explained why investors adopted herd behavior. Further, for investors aged below 30 years, the hasty decision had higher coefficient while for investors aged above 30 years, the coefficient of overconfidence was higher. Similarly, for both less experienced and experienced investors, hasty decision had higher coefficient value. However, the changes in the coefficients were not significant. The result had showed that there were changes in the value of 
NCC JOURNAL - 2019

different variables under different moderation. However, the changes were not significant.

Table 4 Summary of Regression Analysis

\begin{tabular}{lccccc}
\hline \multicolumn{1}{c}{ Variables } & $\begin{array}{c}\text { Without } \\
\text { Moderator }\end{array}$ & $\begin{array}{c}\text { Age } \\
<\mathbf{3 0} \text { Years }\end{array}$ & $\begin{array}{c}\text { Age } \\
>=\mathbf{3 0} \text { Years }\end{array}$ & $\begin{array}{c}\text { Experience } \\
<\mathbf{5} \text { Years }\end{array}$ & $\begin{array}{c}\text { Experience } \\
>=\mathbf{5} \text { Years }\end{array}$ \\
Constant & .693 & .95 & 1.26 & 1.09 & 1.09 \\
Hasty Decision & $.381^{*}$ & $0.56^{*}$ & $.42^{*}$ & $.50^{*}$ & $.43^{*}$ \\
Decision Accuracy & -.068 & $-.04^{*}$ & -.05 & -.05 & -.01 \\
& 0.31 & 0.28 & 0.18 & 0.25 & 0.19 \\
$\mathrm{R}^{2}$ & 0.30 & 0.27 & 0.18 & 0.24 & 0.18 \\
Adjusted R ${ }^{2}$ & $60.17 *$ & $32.52^{*}$ & $26.29 *$ & $34.05^{*}$ & $22.38^{*}$ \\
$\mathrm{~F}$ & & & & & \\
\hline
\end{tabular}

\section{Conclusions}

The study had been carried out to analyze the attitudinal factors specially the herd behavior of the investors in our Nepali context. Since, there were numerous studies that proved the existence of herd behavior in the developed, developing, and emerging markets; but these studies were still insufficient to define what exactly the attitudinal factors to cause herd behavior. The results of the study revealed that there was significant relationship of the hasty decision with herd behavior, while the relationship between decision accuracy and herd behavior was not significant. Moreover, the relationship was not significantly moderated by the presence age or investment experience. Further studies are suggested to incorporate other factors such as mood, insights, peer pressure, market factor, motivation and other dimensions of behavioral finance that might lead to herd behavior. In addition to that, comparison of herding through secondary data obtained from share market, and perception of brokerage firm towards herding of general investors can be another field of study. Similar study can be extended to include both institutional and individual investors to draw comparative conclusions. Moreover, effect of other demographic factors such as income, level of education and gender in creating herd behavior can be measured. Further studies can be carried out to access the impact of development of the new methods such as neuro-economics and behavioral artificial intelligence in behavioral finance and their contribution in the better investment decision making.

\section{Discussions}

As the present study investigated the attitudinal factors that determine the herd behavior of the individual NEPSE investors, the section dealts with the discussion on the issues relating to the relationship between herd behavior with other variables taken under study. However, the study result is highly dominated by the male respondents belonging the age above 30 years and their investment experience less than 5 years without having any professional training regarding the share investment. The result shows that hasty decision had a positive impact in creating herd behavior, while decision accuracy was insignificant in all the models of the study except investors of age below 30 years.For majority of the cases, the result provides the evidences for priori expectation stated in hypothesis 1,3 , and5 and against the hypothesis 2,4 , and 6 . The positive relationship of hasty decision with herd behavior is consistent with the study result of the Susha $\&$ Touny (2016) and other obtained relationships are against the result provided by them. Moreover, the relationship suggests a lot to do with the social structure of our community. Following the elders' order without question is a norm in eastern society which may lead to herding as the elder too is inexperienced in financial market and may make a decision in haste. In the case, the person who follows the orders, due 
Vol. 4, No. 1

to his/her faith in the elder, believes the suggestion is right. When the trend spills over to others investors as well it leads to the adaptation of herd behavior. Herding behavior also results when investors fail to screen the market information due to lack of skills, time constraints or their laziness in tedious calculation. Thus, the investors' decision depends upon the other investors' decision to follow the wisdom of the crowd. The study result provides the strong evidence that the inexperienced investors believe that the time spent in verification of information cause them to lose opportunity to realize profit, that ultimately cause them to trap in hasty decision based on fast, intuitive, and emotional biases. To sum up, the Nepali investors investment decisions seems to be irrational and influenced by their psychological forces so that they get driven towards herd behavior. The investors become the victim of hasty decision to tend to give priority at investment time to the mass decision. Finally, it results the unreasonable movement in the prices of the securities in the market to become the phenomenon of irrational oscillation between bull and bearish trend.

\section{References}

American Psychological Association. (2009). Publication Manual of the American Psychological Association. Washington, USA: APA Service Center

Adhikari, P. (2010). Investment Behaviour of Nepali Investors. PYC Nepal Journal of Management, 3(1), 47-58.

Ah Mand, et.,al. (2018). Determinants of Herding Behavior in Malaysian Stock Market. International Journal of Economics Research, 9(1), 75-86.

Ajzen, I. (1991). The Theory of Planned Behavior. Organizational Behavior and Human Decision Processes, 50(2), 179-211.

Ajzen, I. (2002). Perceived Behavioral Control, Self-Efficacy, Locus of Control, and the Theory of Planned Behavior. Journal of Applied Social Psychology, 32(4), 665-683. doi:10.1111/j.1559-1816.2002. tb00236.x

Ajzen, I., \& Fishbein, M. (1980). Understanding Attitudes and Predicting Social Behavior. Englewood Cliffs, New Jersy: Prentice-Hall.

Barberis, N., \& Thaler, R. (2003). A Survey of Behavioral Finance. In G. Constantinides, M. Harris, \& R. Stulz, Handbook of the Economics of Finance (pp. 1052-1090). Chicago: Elsevier Science B.V.

Basu, S. (1997). Investment Performance of Common Stock in Relation to Their Price Earning Ratios: A Test of Efficient Market Hypothesis. Journal of Finance, 32(3), 663-682.

Bikhchandani, S., \& Sharma, S. (2001). Herd Behavior in Financial Markets. IMF Staff Paper, 47(3), 279310.

Bikhchandani, S., Hirshleifer, D., \& Welch, I. (1992). A Theory of Fads, Fashion, Custom, and Cultural Changes as Informational Cascades. Journal of Political Economy, 100(5), 992-1026.

Bondt, W. F., \& Thaler, R. H. (1995). Financial Decision-Making in Markets and Firms: A Behavioral Perspective. Handbooks in Operations Research and Management Science, 9, 385-410.

Chaffai, M. (2017). Herding Behavior in Islamic GCC Market: A Daily Analysis. Islamic Journal of Islamic and Middle Eastern Finance and Management, Vol. 11 (2), pp. 182-193.

Chiang, T. C., Li, J., \& Tan, L. (2010). Empirical Investigation of Herding Behavior in Chinese Stock Markets: Evidence from Quantile Regression Analysis. Global Finance Journal, 21(1), 111-124.

Christie, W. G., \& Huang, R. D. (1995). Following the Pied Piper: Do Individual Returns Herd around the Market? Financial Analysts Journal, 51(4), 31-37.

Dangol, R., \& Sthapit, A. (2017). Impact of Herding Behaviour and Overconfidence Bias on Individual Investor's Investment Decision: A Study of Nepali Stock Market. ORSN National Conference 2017, p. 
38.

Devenow, A., \& Welch, I. (1996). Rational Herding in Financial Economics. European Economic Review, 40(3), 603-615.

Gujrati, D. N. (2004). Basic Econometrics. New York: The McGraw-Hill Companies.

Hair, J. F., Black, B., Babin, B., Anderson, R. E., \& Tatham, R. L. (1998). Multivariate Data Analysis (5th ed.). Person.

Helms, J. E., Henze, K. T., Sass, T. L., \& Mifsud, V. A. (2006). Treating Cronbach's Alpha Reliability Coefficients as Data in Counseling Research. The Counseling Psychologist, 34, 630-660.

Insana, R. (2017). Bitcoin is in a Bubble, and Here'S How It'S Going to Crash. Retrieved from CNBC: https://www.cnbc.com/2017/09/13/bitcoin-is-in-a-bubble-and-heres-how-its-going-to-crash-roninsana.html

Keim, D. B. (1983). Size-Related Anomalies and Stock Return Seasonality: Further Empirical Evidence. Journal of Financial Economics, 12(1), 13-32.

Kim, K. A., \& Nofsinger, J. (2008). Behavioral Finance in Asia. Pacific-Basin Finance Journal, 16, 1-7.

Nicholson, S. F. (1968). Price Ratios in Relation to Investment Results. Financial Analysts Journal, 105-109.

Nofsinger, J. R., \& Sias, R. W. (1999, December). Herding and Feedback Trading by Institutional and Individual Investors. The Journal of Finance, 54(6), 2263-2295.

Nunnally, J. C., \& Branstrain, I. H. (1994). Psychometric Theory. New York: McGraw-Hill.

Olsen, R. A. (1997). Investment risk: The experts' perspective. Financial Analysts Journal, 53(2), 62-66.

Ritter, J. R. (2003). Behavioral Finance. Pacific-Basin Finance Journal, 11(4), 429-437.

Scharfstein, D. S., \& Stein, J. C. (1990). Herd Behavior and Investment. The American Economic Review, 80(3), 465-479.

Selltiz, C., Wrightsman, L. S., \& Cook, S. W. (1976). Research Methods in Social Relations. New York: Holt, Rinehart and Winston.

Shefrin, H., \& Statman, M. (1985). The Disposition to Sell Winners too Early and Ride Losers too Long: Theory and Evidence. The Journal of Finance, 40(3), 777-790.

Shiller, R. J. (2000). Irrational exuberance. Princeton: Princeton University Press.

Shiller, R. J., \& Pound, J. (1989). Survey Evidence on Diffusion of Interest and Information Among Investors. Journal of Economic Behavior \& Organization, 12(1), 47-66.

Shleifer, A. (2000). Inefficient Markets: An Introduction to Behavioural Finance. Oxford: Oxford University Press.

Shusha, A. A., \& Touny, M. A. (2016, March). The Attitudinal Determinants of Adopting the Herd Behavior: An Applied Study on the Egyptian Exchange. Journal of Finance and Investment Analysis, 5(1), 55-69.

Tan, L., Chiang, T., Mason, J. R., \& Nelling, E. (2008). Herding Behavior in Chinese Stock Markets: An Examination of A And B Shares. Pacific-Basin Finance Journal, 16(1-2), 61-77.

Thaler, R. H. (1993). Advances in Behavioural Finance; Noise Trader Risk in Financial Markets. Journal of Political Economy, 98(4), 703-738. 